\title{
Characteristics of atmospheric ammonia over Beijing, China
}

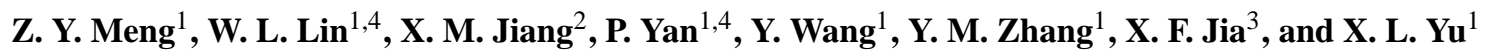 \\ ${ }^{1}$ Key Laboratory for Atmospheric Chemistry, Center for Atmospheric Watch and Services, Chinese Academy of \\ Meteorological Sciences, Beijing, China \\ ${ }^{2}$ Tsinghua University, Beijing, China \\ ${ }^{3}$ Department of Environmental Engineering, School of Civil and Environmental Engineering, University of Science and \\ Technology Beijing, Beijing, China \\ ${ }^{4}$ Meteorological Observation Centre, China Meteorological Administration, Beijing, China
}

Received: 29 November 2010 - Published in Atmos. Chem. Phys. Discuss.: 26 January 2011

Revised: 14 June 2011 - Accepted: 14 June 2011 - Published: 29 June 2011

\begin{abstract}
Continuous measurements of atmospheric ammonia $\left(\mathrm{NH}_{3}\right)$ were conducted using Ogawa passive samplers from February 2008 to July 2010 at an urban site and from January 2007 to July 2010 at a rural site in Beijing, China. $\mathrm{NH}_{4}^{+}$in fine particles was also collected at the rural site during 2008-2009. The field comparison between the Ogawa passive samplers and an active analyzer for $\mathrm{NH}_{3}$ conducted at the urban site assures the quality and accuracy of the measurements. The concentrations of $\mathrm{NH}_{3}$ at the urban site ranged from 0.7 to $85.1 \mathrm{ppb}$, with the annual average of $18.5 \pm 13.8$ and $23.5 \pm 18.0 \mathrm{ppb}$ in 2008 and 2009 , respectively. The $\mathrm{NH}_{3}$ concentrations at the rural site were lower than those at urban site, and varied from 0.8 to $42.9 \mathrm{ppb}$, with the annual average of $4.5 \pm 4.6,6.6 \pm 7.0$ and $7.1 \pm 3.5 \mathrm{ppb}$ in 2007, 2008 and 2009, respectively. The data showed marked seasonal variations at both sites. The results emphasized traffic to be a significant source of $\mathrm{NH}_{3}$ concentrations in winter in urban areas of Beijing. This was illustrated by the strong correlations of $\mathrm{NH}_{3}$ with the traffic related pollutants $\left(\mathrm{NO}_{\mathrm{x}}\right.$ and $\left.\mathrm{CO}\right)$ and also by the bimodal diurnal cycle of $\mathrm{NH}_{3}$ concentrations that was synchronized with traffic. Similar patterns were not observed during the summer, suggesting other non-traffic sources became more important. At the rural site, the daily $\mathrm{NH}_{4}^{+}$concentrations ranged from 0.10 to $36.53 \mu \mathrm{g} \mathrm{m}^{-3}$, with an average of $7.03 \mu \mathrm{g} \mathrm{m}^{-3}$ from June 2008 to December 2009. Monthly $\mathrm{NH}_{3}$ were significantly correlated with $\mathrm{NH}_{4}^{+}$concentrations. Average monthly $\mathrm{NH}_{3} / \mathrm{NH}_{4}^{+}$ratios varied from 0.13 to 2.28 , with an average of 0.73 . $\mathrm{NH}_{4}^{+}$in $\mathrm{PM}_{2.5}$ was primarily associated with $\mathrm{SO}_{4}^{2-}$ at the rural site.
\end{abstract}

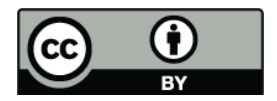

Correspondence to: Z. Y. Meng (jxmxpb@mail.tsinghua.edu.cn)

\section{Introduction}

Atmospheric ammonia $\left(\mathrm{NH}_{3}\right)$ is one of the primary air pollutants, influencing acidic deposition along with sulfur dioxide $\left(\mathrm{SO}_{2}\right)$ and nitrogen oxides $\left(\mathrm{NO}_{\mathrm{x}}\right) . \mathrm{NH}_{3}$ can react with acidic species to form ammonium sulfate $\left[\left(\mathrm{NH}_{4}\right)_{2} \mathrm{SO}_{4}\right]$, ammonium bisulfate $\left(\mathrm{NH}_{4} \mathrm{HSO}_{4}\right)$, ammonium nitrate $\left(\mathrm{NH}_{4} \mathrm{NO}_{3}\right)$, and ammonium chloride $\left(\mathrm{NH}_{4} \mathrm{Cl}\right)$, etc., or deposit onto the Earth's surface. These $\mathrm{NH}_{4}^{+}$aerosols contribute significantly to fine particle mass $\left(\mathrm{PM}_{2.5}\right)$ and have implications for human health (Brunekreef and Holgate, 2002). They limit atmospheric visibility and alter global radiation budgets (Clarisse et al., 2009; Horvath, 1992; Sutton et al., 1994).

Global ammonia emissions have more than doubled since pre-industrial times, largely owing to agricultural intensification and widespread fertilizer use (Galloway et al., 2003). Despite its ecological significance, there are large uncertainties in the magnitude of ammonia emissions, mainly owing to a paucity of ground-based observations and a virtual absence of atmospheric measurements (Asman et al., 1998; Galloway et al., 2008; Dentener et al., 1994; Bouwman et al., 1997, Matthews et al., 1994). Atmospheric $\mathrm{NH}_{3}$ is emitted primarily from livestock wastes (39\%), natural sources (19\%), volatilization of $\mathrm{NH}_{3}$-based fertilizers $(17 \%)$, biomass burning (13\%), crops (7\%) and emissions from humans, pets and waste water (5\%) (Clarisse et al., 2009). Recent evidence suggests that people and traffic may have a greater impact in the non-agricultural regions, where ambient levels of ammonia were found to be higher in more densely populated areas (Suh et al., 1995).

There have been a number of studies of $\mathrm{NH}_{3}$ levels reported from various remote, rural, urban and suburban sites in the world (Galloway et al., 1987; Khemani et al., 1987; Kulshrestha et al., 1996; Lenhard and Gravenhorst, 1980;

Published by Copernicus Publications on behalf of the European Geosciences Union. 
Likens et al., 1987; Possanzini et al., 1988; Tuncel and Ungor, 1996; Chou and Wang, 2007). Clarisse et al. (2009) have retrieved the infrared spectra obtained by the IASI/MetOp satellite to map global ammonia concentrations from space in 2008. They have identified several ammonia hotspots with column above $0.5 \mathrm{mg} \mathrm{m}^{-2}$ in middle-low latitudes across the globe.

Few studies on ammonia emissions in China are available. Along with the rapid growth of the economy in China, the total $\mathrm{NH}_{3}$ emission in 2000 was estimated to be $13.6 \mathrm{Tg}$, of which $50 \%$ comes from fertilizer application and another $38 \%$ from the other agricultural sources (Streets et al., 2003). In spite of this, measurements of $\mathrm{NH}_{3}$ in China are currently sparse. Meng et al. (2010) carried out atmospheric $\mathrm{NH}_{3}$ measurements in ten background or rural sites in China during 2007-2008 and found that the spatial variability of the $\mathrm{NH}_{3}$ concentration was large in China, with higher levels in North, Southwest and East China. Cao et al. (2009) reported the variation of ammonia concentrations in Xi' an. It was found that the average concentrations of $\mathrm{NH}_{3}$ were 18.5 and $20.2 \mathrm{ppb}$ at the urban and suburban sites in Xi' an from April 2006 to April 2007.

Beijing with 19.61 million inhabitants in 2010 is one of megacities in the world (Beijing Municipal Bureau of Statistics, http://www.bjstats.gov.cn). Very rapid economic growth and the urbanization aggravate air pollution problems in Beijing and present a great challenge for both scientific research and management of urban and regional air quality. Yao et al. (2003) measured $\mathrm{NH}_{3}$ concentrations in Beijing in summer 2001 and spring 2002, with the concentrations in the range of 6.6-60.9 ppb. Wu et al. (2009) reported the measurement of acidic gases and ammonia during the summers of 2002 and 2003 at a site in Beijing. Recently, measurements of ammonia were conducted in winter and summer of 2007 at an urban site in Beijing and the daily average $\mathrm{NH}_{3}$ concentrations were in the range of $0.3-63.7 \mathrm{ppb}$ (Ianniello et al., 2010). However, these studies were of short duration. There have been no long-term observations of $\mathrm{NH}_{3}$ in Beijing. In this paper, we present for the first time $\mathrm{NH}_{3}$ measurements from February 2008 to July 2010 at an urban site and from January 2007 to July 2010 at a rural site in Beijing, China, characterizing the levels and variations of ammonia in urban and rural areas over Beijing. In addition, we investigate the impact of surface wind and long-range transport on the $\mathrm{NH}_{3}$ concentrations and the contribution of traffic to ammonia levels in the urban area.

\section{Description of experiment}

\subsection{Measurement sites}

Measurements were conducted at an urban site and a rural site in Beijing. The field descriptions are as follows and the location of the sites are shown in Fig. 1, with the emission data of $\mathrm{NH}_{3}$ for the year 2000 from Streets et al. (2003). The urban site is located in the courtyard of China Meteorological Administration (CMA, $39^{\circ} 56^{\prime} \mathrm{N}, 116^{\circ} 24^{\prime} \mathrm{E}, 50 \mathrm{~m}$ a.s.l.) which is situated in the northwestern urban area of Beijing. Passive samplers were installed on the rooftop of the Chinese Academy of Meteorological Sciences (CAMS) building.

The rural site, Shangdianzi (SDZ, $40^{\circ} 39^{\prime} \mathrm{N}, 117^{\circ} 07^{\prime} \mathrm{E}$, $293.3 \mathrm{~m}$ a.s.l.), is located to the northeast of Beijing, about $150 \mathrm{~km}$ away from the urban center of Beijing. About $55 \mathrm{~km}$ southwest of SDZ is the nearest township, Miyun town with a population of about 0.46 million. SDZ is also one of the WMO/GAW regional background stations in China. The site is on the gentle slope of a small hill. The geography surrounding the station is characterized by rolling hills with farmland, orchard and forests. On the foot of the hill about $2 \mathrm{~km}$ south is the Shangdianzi village with about 1200 inhabitants. The main agricultural products include corn, setaria italica, vegetables and fruit. Ammonium dibasic phosphate and urea are used as fertilizers in the region.

\subsection{Sampling and analysis}

Ammonia samples were collected using Ogawa passive samplers (Ogawa USA, Pompano Beach, Florida). The Ogawa sampler, with two reactive glass-filters impregnated with citric acid, was used to trap and determine ambient $\mathrm{NH}_{3}$ concentrations. At CMA, the sampler was prepared in the laboratory and exposed about 7 days on top of the CAMS building from February 2008 to July 2010. The laboratory blank remained frozen in a refrigerator in the laboratory until analyzed. The prepared samplers were sealed in individual airtight storage vials in the laboratory and shipped in a cooling box to SDZ site. The samplers were deployed by trained SDZ station operators in the thermometer screen $(1.5 \mathrm{~m}$ above the ground), which protects the samplers from rain and direct sunshine. At SDZ, each sampler was exposed about 10 days and samples were collected once per month from January 2007 to August 2009 and three times per month from September 2009 to July 2010. A total of 219 samples were collected at both sites. Field blank measurements were made each month at the SDZ site. The field blank was a loaded sampler taken to and from the field with the other samplers but never removed from its air-tight vial. Both the laboratory and field blanks were prepared and processed at the same time and in the same way as the deployed samplers to determine if contamination occurred during the sampler loading, transport, or analysis.

The concentrations of $\mathrm{NH}_{3}$ were measured in parallel by a $\mathrm{NO}_{\mathrm{x}} / \mathrm{NH}_{3}$ analyzer (EC9842, Ecotech, Australia) for intercomparison with passive sampler from June 2009 to May 2010 at the top of the CMA Training Center building (50 m), $200 \mathrm{~m}$ away from the CAMS building. Trace gases (such as $\mathrm{NO}_{\mathrm{x}}$ and $\mathrm{CO}$ ) were simultaneously determined by a chemiluminescence analyzer (TEI, model 42CTL) for $\mathrm{NO}_{\mathrm{x}}$ and a 


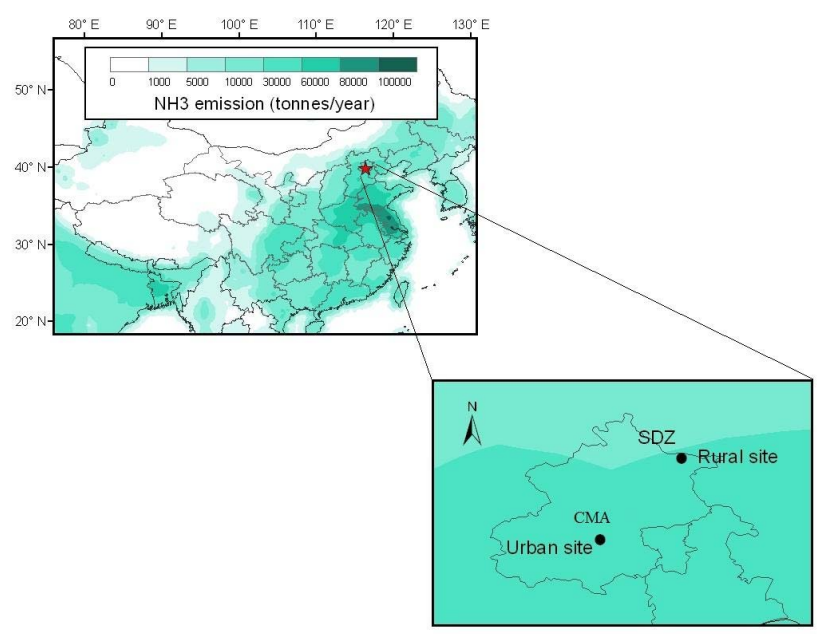

Fig. 1. The sampling locations in Beijing, China with emissions distributions reported by Streets et al. (2003).

gas filter correlation analyzer (TEI, model 48C) for CO on top of the CMA Training Center building.

Daily aerosol $\mathrm{PM}_{2.5}$ samples were collected using the MiniVol portable sampler (Airmetrics, Oregon, USA) operating at flow rates of $5 \mathrm{~L} \mathrm{~min}^{-1}$ from June 2008 to December 2009 at SDZ. PM 2.5 samples were collected on $47 \mathrm{~mm}$ Whatman quartz microfiber filters (QM/A).

In the laboratory, samples were analyzed following the manufacturer's protocols (Ogawa, http://www.ogawausa. com). The two filters of sample can be analyzed independently for the purpose of replication, but in this study both were combined for a single analysis. The mass transfer coefficient at $25^{\circ} \mathrm{C}$ is $15.5 \mathrm{~cm}^{3} \mathrm{~min}^{-1}$ for each filter sampler, and is $31.1 \mathrm{~cm}^{3} \mathrm{~min}^{-1}$ for both filters. The $\mathrm{NH}_{3}$ collection filters were put into $25-\mathrm{ml}$ glass vials containing $8 \mathrm{ml}$ ultrapure water for $30 \mathrm{~min}$ with occasional shaking. The ammonium extract was analyzed using Dionex ICS-3000 Ion Chromatography (Dionex, USA) with a CG12A $4 \mathrm{~mm}$ guard column and a CS12A $4 \mathrm{~mm}$ analytical column. The CSRS (cation selfregenerating suppressor) was set at $50 \mathrm{mV}$. The detector used was a CD conductivity detector. The eluent was methanesulfonic acid (MSA).

$\mathrm{PM}_{2.5}$ filters were extracted with ultrapure water. The concentrations of $\mathrm{NH}_{4}^{+}, \mathrm{NO}_{3}^{-}, \mathrm{SO}_{4}^{2-}$ and $\mathrm{Cl}^{-}$in $\mathrm{PM}_{2.5}$ were also determined by using Dionex ICS-3000.

\subsection{Quality control and inter-comparison for passive samplers}

To prevent the collection filters from deterioration, measures were taken to reduce the time in which the collection filters or the loaded samplers were exposed to warmer conditions. All collection filters were sealed and stored in the refrigerator before being loaded into the samplers. The sampler components, airtight vials, and glass ware were cleaned using ul- tra pure water before reuse. Clean dispensable polyethylene gloves were used to avoid bare hand contact with sampling components. The samplers were assembled and dissembled in a clean laboratory room using clean forceps. Samplers were transported to and from the field in an ice box. Upon retrieval, the exposed samplers were frozen until analysis. The concentrations of $\mathrm{NH}_{3}$ were corrected using field blanks.

For continuous active analyzers (such as $\mathrm{NH}_{3}, \mathrm{NO}_{\mathrm{x}}$ and $\mathrm{CO}$ analyzers), zero and span checks were done every week to check for possible analyzer malfunction and zero drifts. The multi-point calibrations were performed at approximately 1-month interval.

The comparison between the Ogawa passive samplers and a continuous active $\mathrm{NH}_{3}$ analyzer (EC9842, Australia) was carried out at CMA from June 2009 to May 2010. The average $\mathrm{NH}_{3}$ concentrations measured by EC 9842 were averaged over the same time period as the passive samplings. Figure 2 presents the comparisons of $\mathrm{NH}_{3}$ concentrations measured by passive samplers and the active monitor. The 2 -sided linear regression (reduced major axis technique) is performed for the regression statistics. As shown in Fig. 2, the observed results showed a good very significant correlation $(N=42$, slope $=1.21, R=0.77, P<0.0001)$ between the two measurement methods. The low cost in long-term observations, low operating requirements and good agreement with active sampling techniques indicate that the Ogawa passive sampler is an excellent alternative to the other methods for determining $\mathrm{NH}_{3}$ and could find wide application in environmental monitoring studies.

The quality not only depends on the sampler, but also on the analysis and the evaluation of results. The coefficient of variation is a statistical measure of precision based on the difference between duplicate samples. In this study, the coefficients of variation (COV) are defined as the median relative standard deviation, assuming a normal distribution of the deviation between parallel samples. The coefficients of variation of all duplicates were $9.9 \%$ and $6.5 \%$ for urban and rural site, which is acceptable for indicative monitoring.

\section{Results and discussion}

\subsection{Overall results}

\subsubsection{Concentration levels and comparison with other areas}

The statistics of concentrations of $\mathrm{NH}_{3}$ during the sampling period at the two observation sites in Beijing are listed in the Table 1. It is obvious that ammonia concentrations varied greatly between two sites. The concentrations of $\mathrm{NH}_{3}$ at CMA ranged from 0.7 to $85.1 \mathrm{ppb}$, with the annual average concentrations and one standard deviation of $18.5 \pm 13.8 \mathrm{ppb}$ in 2008 and $23.5 \pm 18.0 \mathrm{ppb}$ in 2009 . The $\mathrm{NH}_{3}$ concentrations at SDZ were lower than those at urban site and varied 
Table 1. Annual summary statistics of weekly and monthly average concentration of $\mathrm{NH}_{3}$ at urban and rural site in Beijing, in ppb.

\begin{tabular}{|c|c|c|c|c|c|c|c|c|}
\hline Site & Period & Mean & $\begin{array}{r}\text { Standard } \\
\text { Deviation }\end{array}$ & Minimum & 25 th percentile & 75th percentile & Median & Maximum \\
\hline \multirow{3}{*}{$\begin{array}{l}\text { Urban Site } \\
\text { (CMA) }\end{array}$} & 2008.02-2008.12 & 18.5 & 13.8 & 4.0 & 8.1 & 21.8 & 15.3 & 56.6 \\
\hline & 2009.01-2009.12 & 23.5 & 18.0 & 0.7 & 15.3 & 30.5 & 19.5 & 85.1 \\
\hline & 2010.01-2010.07 & 26.9 & 15.7 & 10.9 & 15.5 & 33.5 & 21.0 & 70.4 \\
\hline \multirow{4}{*}{$\begin{array}{l}\text { Rural Site } \\
\text { (SDZ) }\end{array}$} & 2007.01-2007.12 & 4.5 & 4.6 & 1.2 & 1.5 & 5.5 & 2.4 & 16.2 \\
\hline & 2008.01-2008.12 & 6.6 & 7.0 & 0.8 & 2.1 & 7.0 & 4.5 & 21.6 \\
\hline & 2009.01-2009.12 & 7.1 & 3.5 & 2.6 & 4.4 & 9.0 & 6.3 & 13.8 \\
\hline & $2010.01-2010.07$ & 14.2 & 10.8 & 2.6 & 6.3 & 18.6 & 11.5 & 42.9 \\
\hline
\end{tabular}

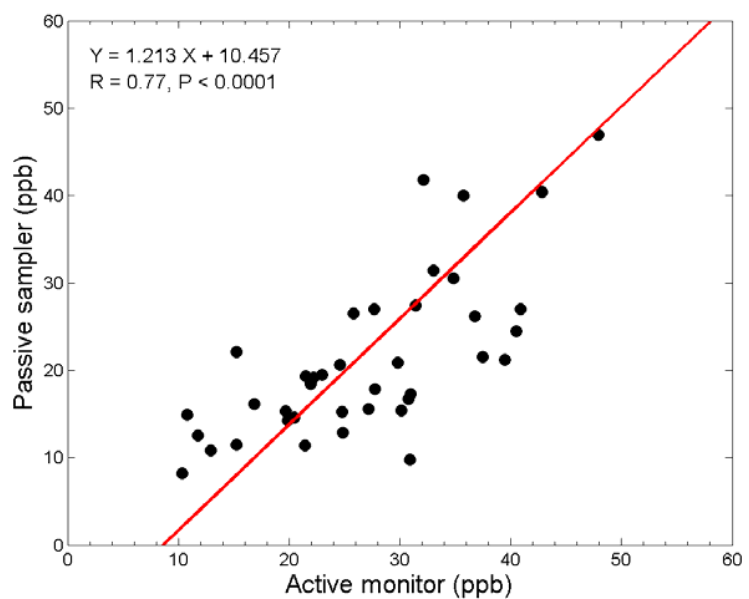

Fig. 2. Comparison of results obtained with the Ogawa passive sampler and an active monitor at CMA from June 2009 to May 2010.

from 0.8 to $42.9 \mathrm{ppb}$, with the annual average concentrations of $4.5 \pm 4.6,6.6 \pm 7.0$ and $7.1 \pm 3.5 \mathrm{ppb}$ in 2007,2008 and 2009, respectively.

Table 2 lists $\mathrm{NH}_{3}$ levels at different urban and suburban sites in the world. The average concentrations of $\mathrm{NH}_{3}$ found at CMA in this study were higher than those obtained in 2001, 2002 and 2003 at Peking University site (PKU) in Beijing reported by Yao et al. (2003) and Wu et al. (2009), and were comparable to those reported by Ianniello et al. (2010) for winter and summer 2007 at PKU site. $\mathrm{NH}_{3}$ concentrations at CMA are higher than the 2001-2003 PKU observations as a result of the substantial increase in vehicle traffic in urban centre of Beijing.

At SDZ, the values during 2007-2010 are obviously higher than that during 1999-2000 reported by Carmichael et al. (2003). Such differences may indicate an increase of $\mathrm{NH}_{3}$ levels in North China Plain. As illustrated, the $\mathrm{NH}_{3}$ level at urban site in Beijing was higher than that reported in $\mathrm{Xi}$ 'an (18.6 ppb) (Cao et al., 2009), at same time, $\mathrm{NH}_{3}$ concentrations at SDZ in Beijing was lower than those in Xi'an suburban site (20.3 ppb), which was consistent with the lower emission data in SDZ regional background station in China.
The $\mathrm{NH}_{3}$ level at CMA in Beijing was also higher than that reported in Rome, Italy, and at the urban site in Croatia near the North Adriatic. $\mathrm{NH}_{3}$ level at Beijing was $2-5$ times higher than that reported at New York, USA, Clinton, Kinston, Morehead City of North Carolina, USA and Hong Kong. The $\mathrm{NH}_{3}$ level at CMA in Beijing was lower than that reported in Lahore, Pakistan. $\mathrm{NH}_{3}$ concentrations at SDZ in Beijing were lower than those at the suburban site in Croatia near the North Adriatic.

The above comparisons suggested that there exist complex $\mathrm{NH}_{3}$ patterns in the Beijing region. More research efforts are needed to quantify the contribution of local versus regional sources to the atmospheric ammonia variations in Beijing.

\subsubsection{Temporal variations}

Figure 3 shows the temporal variation of $\mathrm{NH}_{3}$, temperature and wind speed at the two observation sites. $\mathrm{NH}_{3}$ exhibited a distinct and significant temporal variation with higher concentrations in summer than in other season, especially in winter at both sites. At CMA, $\mathrm{NH}_{3}$ increased gradually from April and reached the highest values on July, and then decreased until the following March. $\mathrm{NH}_{3}$ values had a small peak in April as the temperature increase suddenly caused the accumulated emission of $\mathrm{NH}_{3}$ from natural and fertilized soils, vegetation, and human sources in the city centre in winter. The peak $\mathrm{NH}_{3}$ value was $85.1 \mathrm{ppb}$ on $20-24$ July 2009 and the lowest concentrations of $\mathrm{NH}_{3}(0.7 \mathrm{ppb})$ appeared on 18-24 February 2009 for over two-year period 2008-2010 (Fig. 3a). The annual average temperatures were $14.0^{\circ} \mathrm{C}, 14.1^{\circ} \mathrm{C}$ and $14.4^{\circ} \mathrm{C}$ in 2007,2008 and 2009 , respectively, with the highest monthly temperature $\left(28.6^{\circ} \mathrm{C}\right)$ in July of 2010 and the lowest temperature $\left(-3.5^{\circ} \mathrm{C}\right)$ in January of 2010 at CMA (Fig. 3b). The maximum value of $\mathrm{NH}_{3}$ concentration is consistent with the highest ambient temperature in July. The lowest $\mathrm{NH}_{3}$ value was in February 2009 which might be attributable to the cold temperatures, moderate snowfall and less human activity because lots of mobile population moving back to their hometowns during the Chinese Spring Festival. 
Table 2. Comparison of $\mathrm{NH}_{3}$ concentrations in Beijing with other areas, in ppb.

\begin{tabular}{|c|c|c|c|c|c|}
\hline Location & Type & Period & Concentration & measurement techniques & Reference \\
\hline \multirow[t]{2}{*}{ Beijing, China } & Urban & 2008.02-2010.07 & $22.8 \pm 16.3$ & Passive sampler & This study \\
\hline & Rural & 2007.01-2010.07 & $10.2 \pm 10.8$ & & \\
\hline Beijing, China & Urban & 28 July-3 August 2001 & $16.8-42.2$ & Annular denuder & Yao et al. (2003) \\
\hline Beijing, China & Urban & Summer 2002-2003 & 23.9 & Annular denuder & Wu et al. (2009) \\
\hline Beijing, China & Urban & Winter and Summer 2007 & $0.29-63.8$ & Annular denuder & Ianniello et al. (2010) \\
\hline Beijing, China & Rural & $1999.09-2000.05$ & 3.0 & Passive sampler & Carmichael et al. (2003) \\
\hline \multirow[t]{2}{*}{ Xi'an, China } & Urban & 2006.04-2007.04 & 18.6 & Passive sampler & Cao et al. (2009) \\
\hline & Suburban & & 20.3 & & \\
\hline Rome, Italy & Urban & 2001.05-2002.03 & $5.5-65.6$ & Annular denuder & Perrino et al. (2002) \\
\hline New York, USA & Urban & 1999.07-2000.06 & 5.1 & Annular denuder & Bari et al. (2003) \\
\hline Clinton, Carolina, USA & Urban & $2000.01-2000.12$ & 7.7 & Annular denuder & Walker et al. (2004) \\
\hline Kinston, Carolina, USA & Urban & $2000.05-2000.12$ & 3.5 & & \\
\hline Morehead, Carolina, USA & Urban & $2000.01-2000.12$ & 0.8 & & \\
\hline Hong Kong & Urban & Autumn 2000 & 3.0 & Autoanalyser & Yao et al. (2006) \\
\hline Northern Adriatic & Urban & 1998-2005 & $17.3-28.8$ & $\begin{array}{l}\text { Spectrophotometrically } \\
\text { by Nesslerization }\end{array}$ & Alebic-Juretic, (2008) \\
\hline area, Croatia & Suburban & & $8.6-40.3$ & & \\
\hline Lahore, Pakistan & Urban & $2005.12-2006.02$ & $30.3-116.9$ & Annular denuder & Biswas et al. (2008) \\
\hline
\end{tabular}
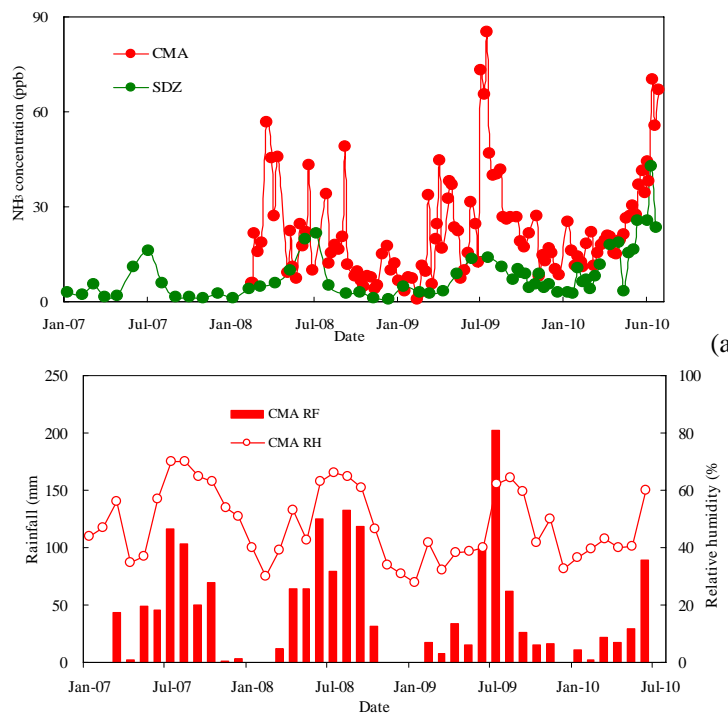

(a)

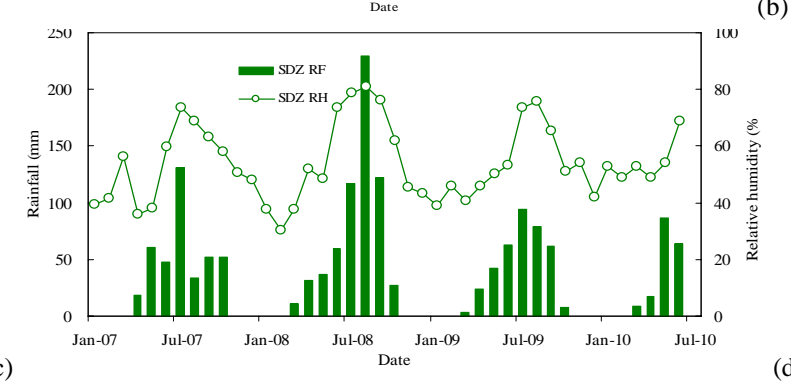

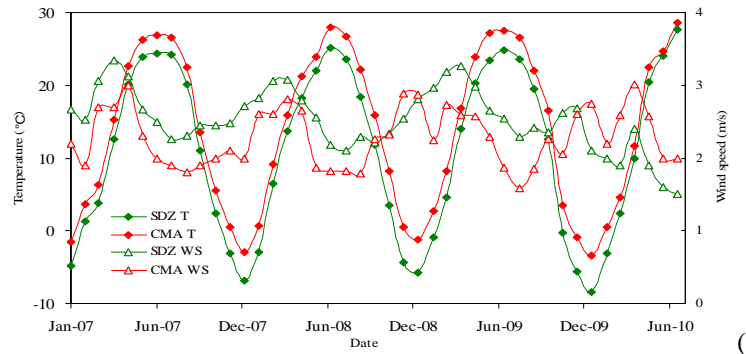

(b)

(d)

Fig. 3. Temporal variations of $\mathrm{NH}_{3}$, temperature $(T)$, wind speed (WS), rainfall (RF) and relative humidity (RH) at CMA and SDZ sites in Beijing during 2007-2010.

At SDZ, the peak $\mathrm{NH}_{3}$ value was $42.9 \mathrm{ppb}$ on 11-21 July 2010 and the lowest concentrations of $\mathrm{NH}_{3}(0.8 \mathrm{ppb})$ appeared on 19-29 December 2008 from January 2007 to July 2010. The annual average temperatures at SDZ site were $11.3^{\circ} \mathrm{C}, 10.7^{\circ} \mathrm{C}$ and $10.9^{\circ} \mathrm{C}$ in 2007,2008 and 2009 , respectively, with the highest monthly temperature $\left(27.7^{\circ} \mathrm{C}\right)$ in July of 2010 and the lowest temperature $\left(-8.4^{\circ} \mathrm{C}\right)$ in January of 2010. In summer, high temperatures will favor ammonia volatilization from urea and ammonium dibasic phosphate applied to crops.

$\mathrm{NH}_{3}$ and air temperature were found to be significantly correlated ( $R=0.47$ for CMA and $R=0.62$ for SDZ). This phenomenon showed that the air temperature was one of the key parameters determining ammonia concentration in Beijing, especially at SDZ, because agriculture is the main source of $\mathrm{NH}_{3}$ in this rural area. A positive correlation of $\mathrm{NH}_{3}$ with temperature may be attributable to an increase in $\mathrm{NH}_{3}$ sources via enhanced volatilization of $\mathrm{NH}_{3}$ and/or decreased stability of the $\mathrm{NH}_{4} \mathrm{NO}_{3}$ aerosol. Various studies have shown strong correlations between air temperature and ammonia concentration, suggesting that temperature is an important variable in influencing $\mathrm{NH}_{3}$ volatilization from fertilizer and animal waste (Aneja et al., 2000; Zhang et al., 2010). 
In CMA, the highest annual rainfall $(626.0 \mathrm{~mm})$ was found in 2008 during observation period (Fig. 3c). In 2008, the monthly rainfalls were $125.3,79.3$ and $132.1 \mathrm{~mm}$ in June, July and August, respectively. $\mathrm{NH}_{3}$ concentrations were 17.9, 26.5 and $19.9 \mathrm{ppb}$ in June, July and August of 2008, respectively. Much lower $\mathrm{NH}_{3}$ concentrations were observed (7.4 and $9.7 \mathrm{ppb}$, respectively) on 2-10 June 2008 and 1-8 June 2009, those were rainy days. The highest annual rainfall $(633.9 \mathrm{~mm})$ was also found in 2008 in SDZ during the observation period (Fig. 3d). In 2008, the monthly rainfalls were 104.7, 77.8 and $223.7 \mathrm{~mm}$ in June, July and August, respectively. $\mathrm{NH}_{3}$ concentrations were 19.6, 21.6 and $5.2 \mathrm{ppb}$ in June, July and August of 2008, respectively. The lower $\mathrm{NH}_{3}$ levels were consistent with the heavier rain in summer months, reflecting the important role wet removal plays in influencing the temporal variation in ambient $\mathrm{NH}_{3}$ levels.

\subsection{Seasonal variations}

The seasonal concentration of ammonia is dependent on its source and meteorological conditions. Figure 4 displays the monthly statistics of $\mathrm{NH}_{3}$ concentrations observed at both sites. $\mathrm{NH}_{3}$ values were higher in April, especially at CMA, with the rapidly increase of air temperature after winter. The $\mathrm{NH}_{3}$ emission from natural and fertilized soils, city garbage, and vegetation may be greatly enhanced by the abrupt increase of temperature as the end of winter time. The highest monthly mean $\mathrm{NH}_{3}$ concentration was $48.9 \mathrm{ppb}$ in July and the lowest one was $6.4 \mathrm{ppb}$ in February at CMA. Seasonal average concentrations of $\mathrm{NH}_{3}$ at CMA were 21.6 \pm 9.9 , $33.5 \pm 15.5,16.6 \pm 8.5$ and $10.3 \pm 5.2 \mathrm{ppb}$ in spring, summer, autumn and winter, respectively. The $\mathrm{NH}_{3}$ mean concentrations ratio of summer to winter was 3.2.

As can be seen in Fig. 4, the peak monthly $\mathrm{NH}_{3}$ level was $20.6 \mathrm{ppb}$ in July, which was approximately 8 times higher than that $(2.6 \mathrm{ppb})$ in December at SDZ. Seasonal average concentrations of $\mathrm{NH}_{3}$ at $\mathrm{SDZ}$ were $6.9 \pm 4.9,16.3 \pm 8.8$, $3.7 \pm 3.0$ and $3.3 \pm 2.0 \mathrm{ppb}$ in spring, summer, autumn and winter, respectively. The summer to winter ratio for $\mathrm{NH}_{3}$ concentrations was 4.9 at SDZ. The highly amplified seasonality at SDZ may result primarily from increased emission rates of local agricultural $\mathrm{NH}_{3}$ sources during summer.

The ratio of summer to winter mean concentrations at CMA was lower than that at SDZ, which was consistent with the pattern observed by Walker et al. (2004) at nonagricultural city site. Higher $\mathrm{NH}_{3}$ volatility from city garbage and animal husbandry activities can also increase ambient $\mathrm{NH}_{3}$ concentrations during the summer months. Low $\mathrm{NH}_{3}$ concentrations in winter were attributed to reduced $\mathrm{NH}_{3}$ volatilization when the air temperature was frequently below freezing and there were snows.

Figure 5 shows the wind roses of hourly average $\mathrm{NH}_{3}$ concentrations, wind direction frequencies and wind speeds in different seasons at CMA and SDZ. As shown in Fig. 5b, the dominant winds are from NNE-NE sectors and SE-SSE-S

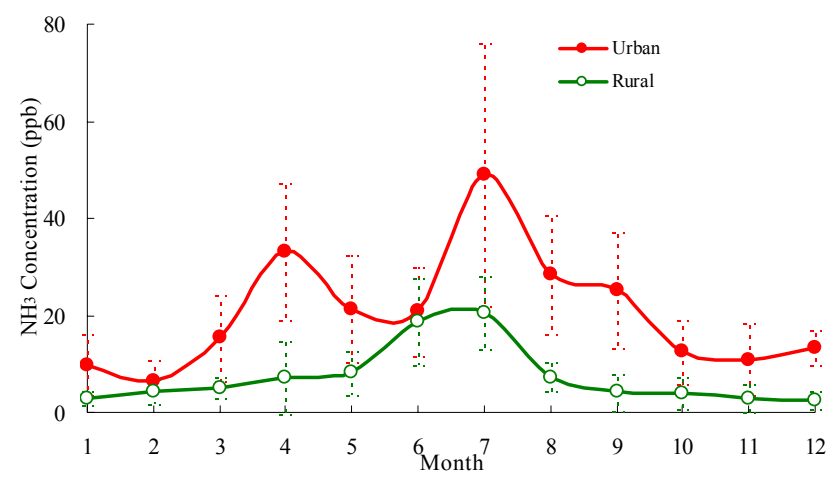

Fig. 4. The statistics of monthly mean concentrations of $\mathrm{NH}_{3}$ during the sampling period at the two observation sites in Beijing.

sectors. The highest and lowest average winds speeds occur under the WNW and WSW sectors, respectively (Fig. 5c). The concentrations of $\mathrm{NH}_{3}$ in different seasons show similar patterns, with the highest values in summer (Fig. 5a). The higher $\mathrm{NH}_{3}$ values were in northeast to southwest sectors and lower values in northwest to north sectors of the urban site. In summer, the average $\mathrm{NH}_{3}$ concentrations in the NNE, $\mathrm{NE}$, ENE, and E sectors were 42.3, 41.9, 39.1, and $40.2 \mathrm{ppb}$, respectively. They are about $10 \mathrm{ppb}$ higher than that in W-N sectors, in which the wind speeds are much stronger. When winds come from northeast direction, the emissions of $\mathrm{NH}_{3}$ from the agricultural areas such as Shunyi district which is located in the suburb northeast of the CMA site might contribute higher levels of $\mathrm{NH}_{3}$. The higher average $\mathrm{NH}_{3}$ concentrations in W and WSW sectors might be attributed to transport of industrial emission from Shijingshan district.

Since $\mathrm{NH}_{3}$ is either readily converted to $\mathrm{NH}_{4}^{+}$or subjected to dry deposition, high concentrations are found only close to the surface and near to emission sources. Thus, $\mathrm{NH}_{3}$ concentrations might be generally lower at higher wind speeds because of turbulent diffusion. The wind speeds were high more than $5 \mathrm{~m} \mathrm{~s}^{-1}$ during spring and winter, with the higher values in summer and autumn in NW-WNW sectors (Fig. 5c). As can be seen in Fig. 5a, the lowest concentrations in four seasons were in these sectors. Previous studies have reported an inverse relationship between ground-level concentrations of trace gases, such as ammonia, and wind speed (Robarge et al., 2002; Lin et al., 2011).

At SDZ, the prevailing winds are northeasterly in autumn and winter and southwesterly in spring and summer (Fig. 5d). The wind direction distribution at SDZ is typical of the larger-scale situation in the North China Plain. Therefore, polluted air masses from urban areas and even those regions in south of Beijing at North China Plain, can be easily transported to SDZ under southwesterly winds, while relatively clean air masses are transported to the site with winds from other directions (Lin et al., 2008). 

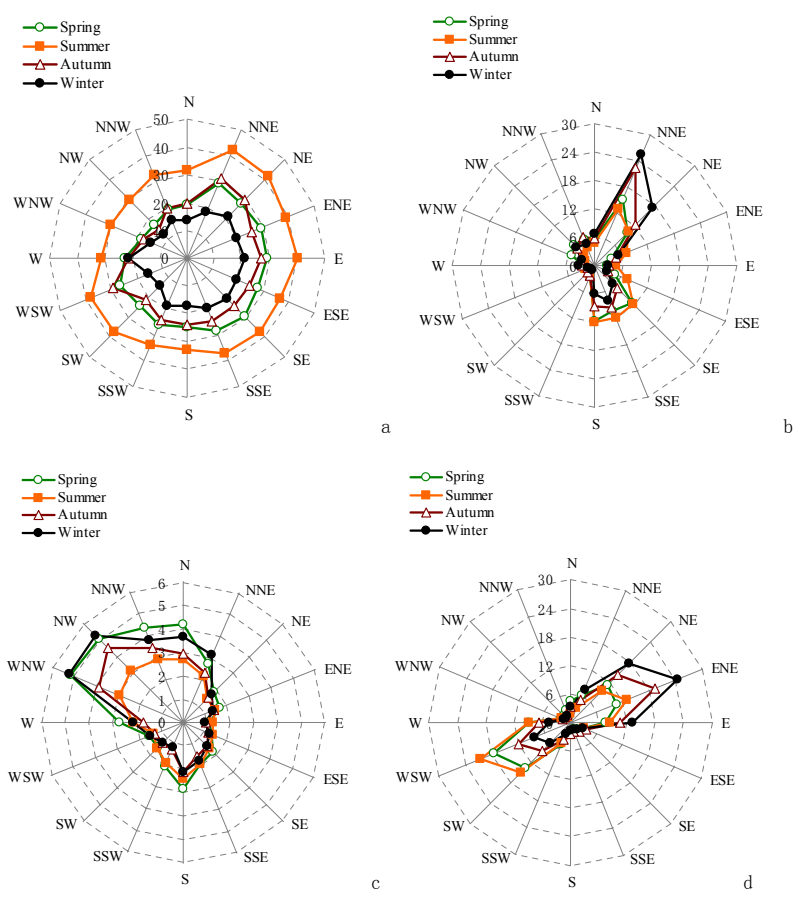

Fig. 5. Seasonal average $\mathrm{NH}_{3}$ concentrations at CMA (a), wind frequency at CMA (b), wind speed at CMA (c) and wind frequency at SDZ (d) distributions in different wind direction sectors during 2009-2010.

The $\mathrm{NH}_{3}$ concentrations at CMA were highly correlated with those at SDZ $(R=0.71, P<0.0001)$. The high correlation of $\mathrm{NH}_{3}$ at two typical sites may point to that $\mathrm{NH}_{3}$ at both sites are affected by similar synoptic conditions.

\subsection{The impact of long-rang air transport on the surface $\mathrm{NH}_{3}$ levels}

While the wind roses provide insight into the distribution of local emission sources around the monitoring site, trajectory analysis are further used to identify the impact of long-range air transport on the surface air pollutants levels (Meng et al., 2007, 2009). The 72-h backward trajectories were calculated using the HYSPLIT 4.9 model (http: //www.arl.noaa.gov/ready/hysplit4.html). The trajectory calculations were done for four times of each day from July 2009 to June 2010, with the four time points of 00:00, 06:00, 12:00, and 18:00 UTC, respectively. The various back trajectories were grouped into 6 clusters. As can be seen in Fig. 6, Clusters 1, 2 and 5 represent relatively low and slow moving air parcels, with cluster 2 coming from southeast areas at the lowest transport height among the 6 clusters. The other three clusters represent air parcels mainly from the northwest. These clusters of trajectories originated from clean regions and travelled quickly from higher atmosphere to Beijing, which is expected to bring cleaner air masses into surface. The cluster 2 from the North China Plain region was

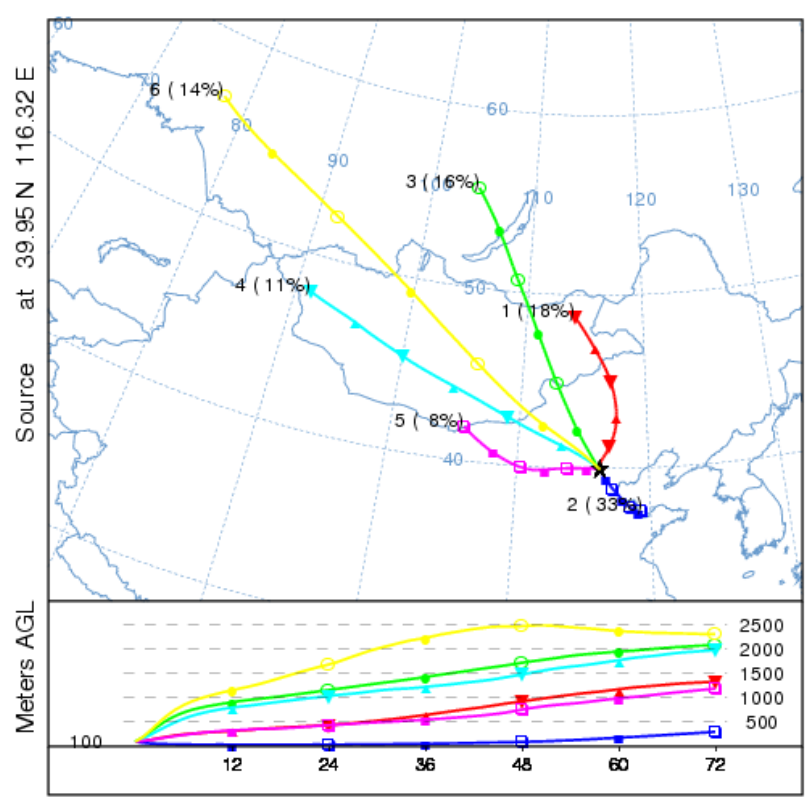

Fig. 6. 72-h backward trajectories for $100 \mathrm{~m}$ above ground level at CMA during July 2009 to June 2010.

most important for the Beijing urban site, contributing $33 \%$ of air masses.

To know the seasonal variations in the trajectories, the occurrence frequencies of each type of air masses arriving at CMA in different seasons were calculated and are shown in Table 3. The corresponding mean concentrations of $\mathrm{NH}_{3}$ in different clusters of backward trajectories are also included in Table 3 in order to characterize the dependences of the pollutants concentrations on air masses. Based on this table, much more trajectories in cluster 2 occurred in summer months, more trajectories in cluster 6 occurred in winter, and more trajectories in cluster 1 occurs in spring.

Large differences in the concentrations of $\mathrm{NH}_{3}$ exist among the different clusters, with cluster 2 corresponding to the highest $\mathrm{NH}_{3}$ levels $(25.7 \mathrm{ppb})$, and cluster 5 corresponding to the second highest $\mathrm{NH}_{3}$ levels (24.4 ppb). These two types of trajectories have the shortest transport distances and lowest transport heights, which help the accumulation of $\mathrm{NH}_{3}$. In addition, the different source areas as the different types of trajectories originated or passed over will also give different contributions to surface levels of $\mathrm{NH}_{3}$.

A detailed estimate of $\mathrm{NH}_{3}$ emission in Beijing and the surrounding areas in 2005 , carried out by Ianniello et al. (2010), has shown that the largest sector contributor to $\mathrm{NH}_{3}$ emissions in the North China Plain (NCP) is agriculture, while mineral fertilizer use contributing $54 \%$ to the total $\mathrm{NH}_{3}$ emission, and livestock sources contributing the remaining $46 \%$ in the NCP. Of the total agricultural ammonia emissions in the NCP, the Hebei, Henan and Shandong provinces take the larger part (Zhang et al., 2010). 
Table 3. Occurrence frequency and mean values of $\mathrm{NH}_{3}$ for each type of air masses arriving at CMA during July 2009 to June 2010.

\begin{tabular}{lrrrrrrr}
\hline Air mass & Spring & Summer & Autumn & Winter & Ratio & Height (m) & $\mathrm{NH}_{3}(\mathrm{ppb})$ \\
\hline Cluster 1 & 92 & 49 & 56 & 66 & $18 \%$ & 722 & 18.1 \\
Cluster 2 & 105 & 268 & 81 & 23 & $33 \%$ & 100 & 25.7 \\
Cluster 3 & 66 & 14 & 83 & 69 & $16 \%$ & 1420 & 11.9 \\
Cluster 4 & 37 & 11 & 54 & 63 & $11 \%$ & 1260 & 16.3 \\
Cluster 5 & 13 & 22 & 47 & 28 & $8 \%$ & 629 & 24.4 \\
Cluster 6 & 51 & 0 & 39 & 107 & $14 \%$ & 1913 & 12.0 \\
\hline
\end{tabular}

Contributions of $\mathrm{NH}_{3}$ emissions from livestock and fertilizer activities were also found in Inner Mongolia (Klimont, 2001; Ju et al., 2004).

Since cluster 2 represents air masses originating from $\mathrm{NCP}$, it is not surprising that the highest $\mathrm{NH}_{3}$ levels were observed in this cluster of air mass trajectories. Air masses in cluster 5 traveled over China's key coal mining and power generation regions in Inner Mongolia, Shanxi Province, and Hebei Province (e.g., Datong, Zhangjiakou, etc.). This explains the second highest $\mathrm{NH}_{3}$ levels corresponding to cluster 5. The cluster 1 has the third highest concentration of $\mathrm{NH}_{3}$. The data in Table 3 suggest that the $\mathrm{NH}_{3}$ concentrations corresponding to clusters 3,4 and 6 are low. This is attributable to the less polluted air over the northwest sector and the higher traveling heights and speeds of air mass with good atmospheric mixing and dilution.

Overall, the air masses from the North China Plain region contain the highest concentration of $\mathrm{NH}_{3}$, and the air masses traveling over the coal mining and power generation regions west of Beijing contain the second highest concentrations of ammonia. Therefore, transport of air masses from these regions is responsible for the high concentrations of $\mathrm{NH}_{3}$ at urban site.

\subsection{Relationship with $\mathrm{NO}_{\mathrm{x}}$ and $\mathrm{CO}$ in different seasons at urban site}

Although agriculture is the main source of atmospheric ammonia for the whole Beijing area, the contribution of vehicles equipped with catalytic converters, especially since the introduction of three-way-catalysts, to non-agricultural $\mathrm{NH}_{3}$ emissions has recently been considered and might be the most important factor influencing ammonia concentrations at urban locations and near roads (Sutton et al., 2000; Kean et al., 2000; Huai et al., 2005; Tanner, 2009; Heeb et al., 2008; Saylor et al., 2010). Since 2009 the total number of vehicles registered in Beijing city had increased to about 4.1 million and is still increasing by more than $10 \%$ per year (Wang et al., 2010). Therefore, in order to examine the contribution of traffic to $\mathrm{NH}_{3}$ concentrations, it may be useful to compare the ammonia concentrations with those of primary pollutants mainly emitted by motor-vehicle exhausts, such as nitrogen oxides $\left(\mathrm{NO}_{\mathrm{x}}\right)$ and carbon monoxide (CO). Hao et al. (2005) estimated that the emissions in Beijing from vehicles, power plants, and industries in 1999 accounted for $35 \%, 27 \%$ and $26 \%$ in the total local $\mathrm{NO}_{\mathrm{x}}$ emissions, respectively.

The scatter plots of the hourly concentration of $\mathrm{NH}_{3}$ versus $\mathrm{NO}_{\mathrm{x}}$ and $\mathrm{NH}_{3}$ versus $\mathrm{CO}$ obtained by continuous active analyzers at CMA from June 2009 to May 2010 are reported in Figs. 7 and 8. As the concentrations of $\mathrm{NH}_{3}, \mathrm{NO}_{\mathrm{x}}$ and $\mathrm{CO}$ are independently measured, an alternative 2 -sided linear regression (reduced major axis technique) is performed for the regression statistics. To do this, the errors come from all the variables $\left(\mathrm{NH}_{3}, \mathrm{NO}_{\mathrm{x}}\right.$ and $\left.\mathrm{CO}\right)$ are considered. The slope value of 0.84 of $\mathrm{NH}_{3} / \mathrm{NO}_{\mathrm{x}}$ in summer indicates the comparable levels of $\mathrm{NH}_{3}$ with $\mathrm{NO}_{x}$ (Fig. 7). In autumn and winter, the levels of $\mathrm{NH}_{3}$ are about one third of the levels of $\mathrm{NO}_{\mathrm{x}}$. The intercepts $\left(\left[\mathrm{NO}_{\mathrm{x}}\right]=0 ;[\mathrm{CO}]=0\right)$ tell us the regional background of $\mathrm{NH}_{3}$ (sources different with $\mathrm{NO}_{\mathrm{x}}$ ) in spring, summer, and autumn were within 4-14 ppb with the maximum one in summer. The regional background of $\mathrm{NH}_{3}$ in winter was less than $1 \mathrm{ppb}$ which also indicates the similar source between $\mathrm{NO}_{\mathrm{x}}, \mathrm{CO}$ and $\mathrm{NH}_{3}$ in winter Beijing.

The correlation coefficients $(R)$ of $\mathrm{NH}_{3}$ versus $\mathrm{NO}_{\mathrm{x}}$ were $0.32,0.15,0.29$ and 0.78 in spring, summer, autumn and winter, respectively. The correlation coefficients $(R)$ of $\mathrm{NH}_{3}$ versus $\mathrm{CO}$ were $0.45,0.32,0.37$ and 0.71 in spring, summer, autumn and winter, respectively. The correlations are all in a very significant level $(P<0.001)$.

It was noted that the correlations of $\mathrm{NH}_{3}$ versus $\mathrm{NO}_{\mathrm{x}}$ and $\mathrm{NH}_{3}$ versus $\mathrm{CO}$ are the best in winter and poorest in summer, which implies that the variations of these species in winter and summer are driven by different dominant processes. The positive linear relationship observed between $\mathrm{NH}_{3}$ versus $\mathrm{NO}_{\mathrm{x}}$ and $\mathrm{NH}_{3}$ versus $\mathrm{CO}$ in winter emphasized that traffic is a significant source of ammonia in urban areas of Beijing. However, in other seasons, especially in summer, less correlation of $\mathrm{NH}_{3}$ versus $\mathrm{NO}_{\mathrm{x}}$ and $\mathrm{NH}_{3}$ versus $\mathrm{CO}$, suggesting that other, non-traffic sources became more important. The higher temperatures in summer will increase emission from biological sources in the city such as humans, sewage treatment and landfill. The volatilization of $\mathrm{NH}_{3}$ from the aerosol phase may be significant enough to dominate over traffic emissions during summer in Beijing. In addition, as 

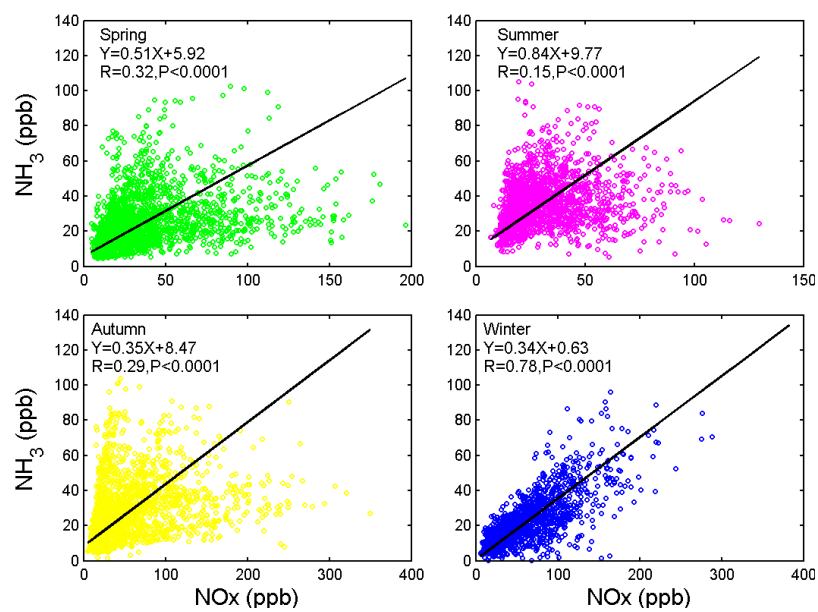

Fig. 7. The 2-sided regression of $\mathrm{NH}_{3}$ versus $\mathrm{NO}_{\mathrm{x}}$ at CMA in different seasons from June 2009 to May 2010.

a site in urban city centre, other emission sources due to human activity, such as solvent use (Whitehead et al., 2007) and house concrete walls (Bai et al., 2006), can be also as $\mathrm{NH}_{3}$ contributors.

\subsection{Diurnal variations at urban site}

The average diurnal variations of $\mathrm{NH}_{3}$ in different seasons during June 2009 to May 2010 at CMA are shown in Fig. 9a. Ammonia gas showed a significant diurnal variation in summer. The concentration of $\mathrm{NH}_{3}$ increased slightly, with a broad peak in the morning (between 07:00 and 11:00 Beijing Standard Time (BST)). The winter diurnal pattern of $\mathrm{NH}_{3}$ is considerably different to that of summer. A bimodal diurnal cycle of $\mathrm{NH}_{3}$ concentration was seen in winter, with higher values in the morning (18.9 ppb, 09:00 BST) and in the evening (22.4 ppb, 22:00 BST). There is no apparent difference between bimodal patterns of spring and autumn, with minima and maxima in the afternoon and evening, respectively. Higher concentrations at night in winter were likely the result of accumulation, stronger temperature inversion and low mixing depth.

As described above, the best relationships of $\mathrm{NH}_{3}$ versus $\mathrm{NO}_{\mathrm{x}}$ and $\mathrm{NH}_{3}$ versus $\mathrm{CO}$ correlations in winter indicated that these gases are mainly emitted from a predominant source in winter. Figure $9 \mathrm{~b}$ compared diurnal variations of $\mathrm{NH}_{3}$ with that of $\mathrm{NO}_{\mathrm{x}}$ and $\mathrm{CO}$, the traffic related pollutants in winter. Figure $9 b$ showed that $\mathrm{NO}_{\mathrm{x}}$ peaks during rush hour at 08:00 BST with $73.3 \mathrm{ppb}$, and then decreased with a minimum (47.8 ppb) at 15:00 BST. After 15:00 BST, $\mathrm{NO}_{\mathrm{x}}$ values began rising again as traffic volume picks up in late afternoon, leading to a second peak (78.3 ppb) at 22:00 BST. Similarly, CO values decreased gradually from early morning, but reached a higher value (1579 ppb) at 08:00 BST. After 16:00 BST, CO values began rising again with a highest
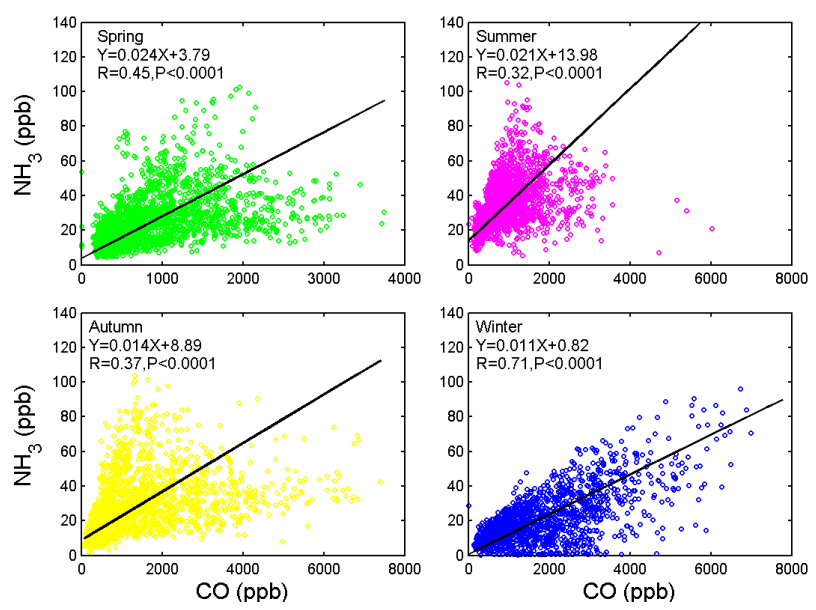

Fig. 8. The 2-sided regression of $\mathrm{NH}_{3}$ versus $\mathrm{CO}$ at CMA in different seasons during June 2009 to May 2010.
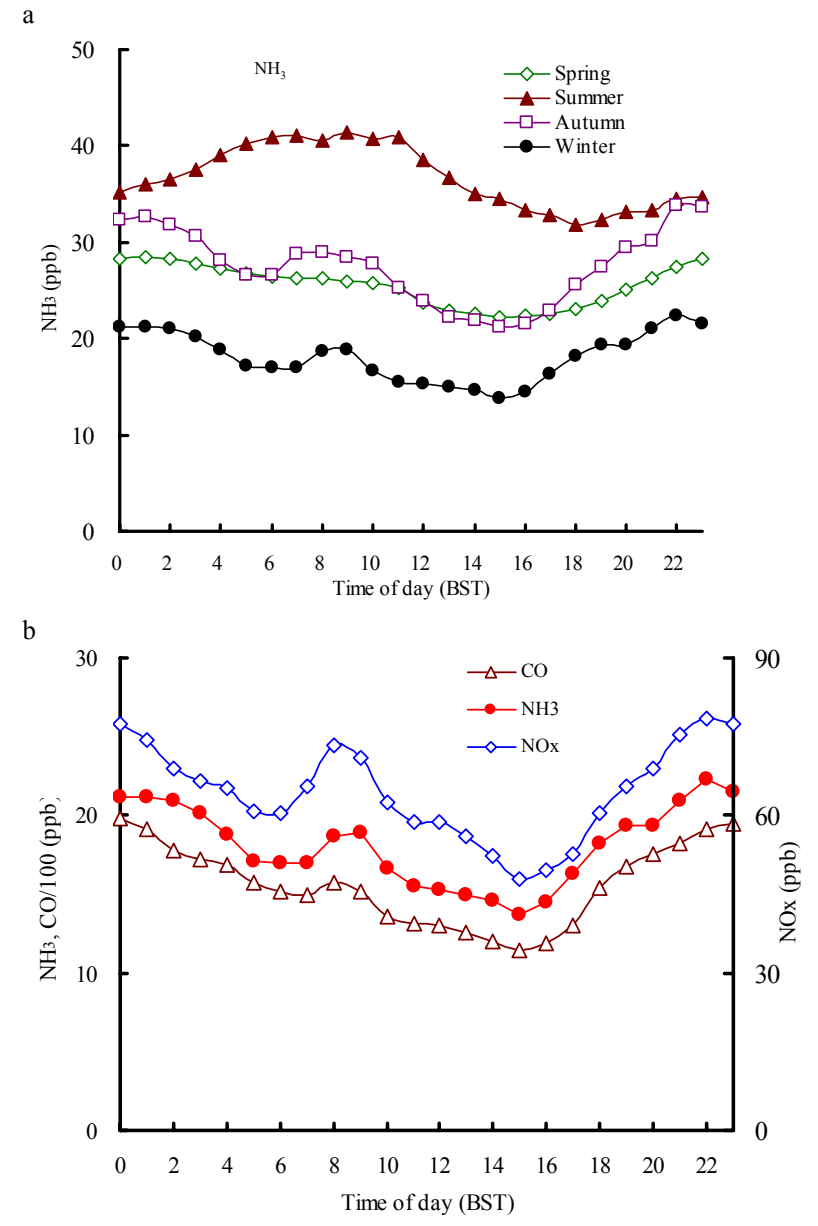

Fig. 9. Averaged diurnal variations of $\mathrm{NH}_{3}$ at $\mathrm{CMA}$ in four seasons during June 2009 to May 2010 (a), and $\mathrm{NO}_{\mathrm{x}}$ and CO in winter 2009 (b). 


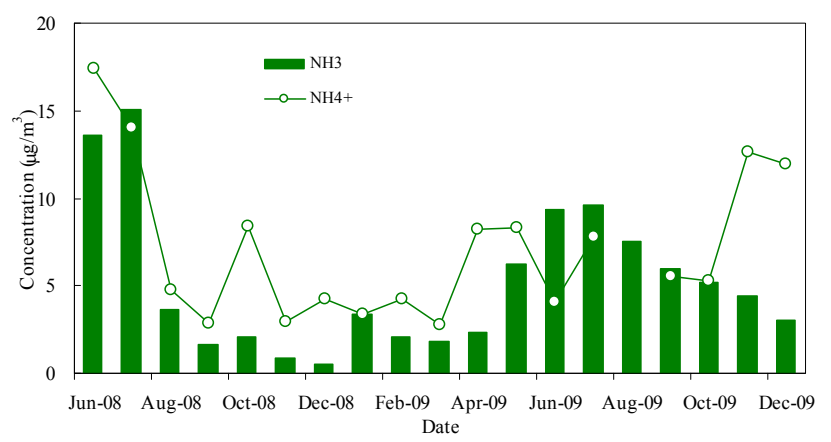

Fig. 10. Temporal variations of monthly concentrations for $\mathrm{NH}_{3}$ and $\mathrm{NH}_{4}^{+}$in $\mathrm{PM}_{2.5}$ at SDZ from June 2008 to December 2009.

level (1952 ppb) at 24:00 BST. The peak $\mathrm{NH}_{3}$ occurred during the morning rush hour similar to $\mathrm{NO}_{\mathrm{x}}$ and $\mathrm{CO}$ supports the hypothesis that the enhanced $\mathrm{NH}_{3}$ level at this time was a direct contribution of the higher traffic volumes. No bimodal pattern is seen in summer, which implies that traffic is not the dominant source of $\mathrm{NH}_{3}$. Greater emission from other sources combined with greater volatilization from the aerosol phase appeared to dominate (Whitehead et al., 2007).

\subsection{Relationship between $\mathrm{NH}_{3}$ and $\mathrm{NH}_{4}^{+}$in $\mathrm{PM}_{2.5}$ at rural site}

Ammonia is a very reactive gas, which plays a major role in the neutralization of atmospheric sulfuric and nitric acid to form ammonium salts. Particulate ammonium $\left(\mathrm{NH}_{4}^{+}\right)$has a longer atmospheric lifetime than $\mathrm{NH}_{3}$ and can therefore be transported over relatively long distances. Deposition of $\mathrm{NH}_{3}$ and $\mathrm{NH}_{4}^{+}$to the Earth's surface can fertilize nitrogenlimited ecosystems, and have detrimental effects such as eutrophication, soil acidification, and biodiversity loss in sensitive ecosystems (Ellis et al., 2010 and 2011; Galloway et al., 2003). To understand the transformation of $\mathrm{NH}_{3}$ and $\mathrm{NH}_{4}^{+}$, the data of $\mathrm{NH}_{4}^{+}$in $\mathrm{PM}_{2.5}$ were collected at SDZ. A total of $117 \mathrm{PM}_{2.5}$ samples were analyzed for the period from June 2008 to December 2009.

The daily $\mathrm{NH}_{4}^{+}$concentrations ranged from 0.10 to $36.53 \mu \mathrm{g} \mathrm{m}^{-3}$, with an average concentration of $7.03 \mu \mathrm{g} \mathrm{m}^{-3}$. Figure 10 illustrates the temporal variations of monthly concentrations for $\mathrm{NH}_{3}$ and $\mathrm{NH}_{4}^{+}$in $\mathrm{PM}_{2.5}$. The average concentrations of $\mathrm{NH}_{4}^{+}$were $7.44,9.04,5.75$ and $4.73 \mu \mathrm{g} \mathrm{m}^{-3}$ in spring, summer, autumn and winter, respectively. The summer to winter ratio for $\mathrm{NH}_{4}^{+}$concentrations was approximately 2.0. $\mathrm{NH}_{3}$ concentrations were lower than $\mathrm{NH}_{4}^{+}$in spring, autumn and winter, but higher than $\mathrm{NH}_{4}^{+}$in summer. $\mathrm{NH}_{3}$ may undergo conversion to $\mathrm{NH}_{4}^{+}$aerosol in the atmosphere, which depends on the concentration of acids in the atmosphere, temperature, and water availability (Kobara et al., 2007), as well as flux rates of $\mathrm{NH}_{3}$ (Nemitz et al., 2001).
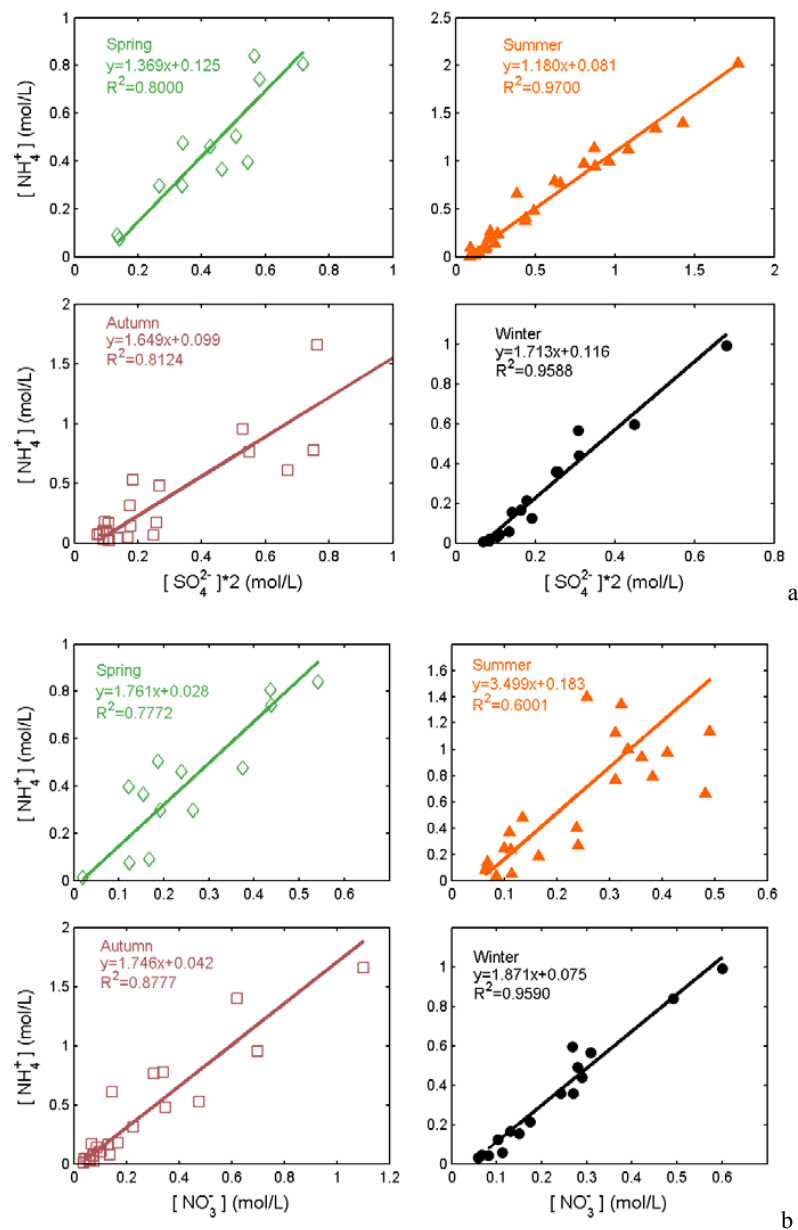

Fig. 11. The relationships of observed $\left[\mathrm{NH}_{4}^{+}\right]$concentrations vs. $2\left[\mathrm{SO}_{4}^{2-}\right]$ and $\left[\mathrm{NO}_{3}^{-}\right]$concentrations in different seasons. The reduced major axis regression is performed for the linear fit.

Monthly $\mathrm{NH}_{3}$ concentrations were significantly correlated with $\mathrm{NH}_{4}^{+}$concentrations $(R=0.64, P<0.0001)$. Average monthly $\mathrm{NH}_{3} / \mathrm{NH}_{4}^{+}$ratios varied from 0.13 to 2.28 , with an average of 0.73 . The highest $\mathrm{NH}_{3} / \mathrm{NH}_{4}^{+}$ratio was found in June 2009, implying that abundant $\mathrm{NH}_{3}$ gas existed in the atmosphere in summer. The lowest $\mathrm{NH}_{3} / \mathrm{NH}_{4}^{+}$ratio appeared in December 2008.

Table 4 summarizes the daily concentrations of inorganic ions in $\mathrm{PM}_{2.5}$ from June 2008 to December 2009. The average concentrations of $\mathrm{SO}_{4}^{2-}, \mathrm{NO}_{3}^{-}$and $\mathrm{Cl}^{-}$were 15.00 , 11.57 and $1.33 \mathrm{\mu g} \mathrm{m}^{-3}$, respectively, and the total concentration of inorganic ions $\left(\mathrm{NH}_{4}^{+}+\mathrm{NO}_{3}^{-}+\mathrm{SO}_{4}^{2-}+\mathrm{Cl}^{-}\right)$was $34.93 \mu \mathrm{g} \mathrm{m}^{-3}$.

With respect to percentage of the total mass, $\mathrm{SO}_{4}^{2-}$ was the most important species on average in $\mathrm{PM}_{2.5}$ at SDZ. Nitrate contributes more significantly to total mass during colder months when $\mathrm{SO}_{2}$ oxidation rates are reduced in response to lower concentrations of oxidants such as $\mathrm{OH}$. The average 
Table 4. Summary statistics of daily average concentration of inorganic ions in $\mathrm{PM}_{2.5}$ from June 2008 to December 2009 at $\mathrm{SDZ}$, in $\mu \mathrm{g} \mathrm{m}^{-3}$.

\begin{tabular}{lrrrrrrr}
\hline Ions & Mean & $\begin{array}{r}\text { Standard } \\
\text { Deviation }\end{array}$ & Minimum & 25th percentile & 75th percentile & Median & Maximum \\
\hline $\mathrm{NH}_{4}^{+}$ & 7.03 & 7.76 & 0.10 & 1.05 & 10.67 & 3.83 & 36.53 \\
$\mathrm{NO}_{3}^{-}$ & 11.57 & 11.40 & 1.14 & 3.32 & 17.15 & 7.10 & 68.24 \\
$\mathrm{SO}_{4}^{2-}$ & 15.00 & 15.68 & 0.58 & 4.48 & 21.23 & 8.56 & 85.31 \\
$\mathrm{Cl}^{-}$ & 1.33 & 1.29 & 0.01 & 0.55 & 1.57 & 0.96 & 8.60 \\
\hline
\end{tabular}

molar ratios of $\mathrm{NH}_{4}^{+}$to $\mathrm{SO}_{4}^{2-}, \mathrm{NO}_{3}^{-}$to $\mathrm{NH}_{4}^{+}$and $\mathrm{Cl}^{-}$to $\mathrm{NH}_{4}^{+}$ were $1.8,0.5$ and 0.1 , respectively.

Figure 11a shows the relationship of the molar concentrations between $\left[\mathrm{NH}_{4}^{+}\right]$and $2 *\left[\mathrm{SO}_{4}^{2-}\right]$ in different seasons. According the values of the different slopes, the lowest value of 1.18 is found in summer and the highest one of 1.71 is found in winter. The slope in spring is a little higher than that in summer and the slope in autumn is close to that in winter. In summer, the mean concentration of $\mathrm{SO}_{4}^{2-}$ and $\mathrm{NH}_{4}^{+}$are the highest but the ratio of $\left[\mathrm{NH}_{4}^{+}\right] /\left(2 *\left[\mathrm{SO}_{4}^{2-}\right]\right)$ is the lowest among the 4 seasons. Figure $11 \mathrm{~b}$ shows the relationship of the molar concentrations between $\left[\mathrm{NH}_{4}^{+}\right]$with $\left[\mathrm{NO}_{3}^{-}\right]$in different seasons. The highest slope of 3.50 is found in summer and the similar values among the other three seasons. In summer, the relationship of $\left[\mathrm{NH}_{4}^{+}\right]$with $\left[\mathrm{NO}_{3}^{-}\right]$is less strong than that of $\left[\mathrm{NH}_{4}^{+}\right]$and $2 *\left[\mathrm{SO}_{4}^{2-}\right]$ and the mean concentration of $\left[\mathrm{NO}_{3}^{-}\right]$is less than the mean concentration of $2 *\left[\mathrm{SO}_{4}^{2-}\right]$, which indicate most of $\mathrm{NH}_{4}^{+}$in aerosol in summer is present as $\left(\mathrm{NH}_{4}\right)_{2} \mathrm{SO}_{4}$. The considerable levels between $\left[\mathrm{NO}_{3}^{-}\right]$and $2 *\left[\mathrm{SO}_{4}^{2-}\right]$ in winter and both strong correlations between $\left[\mathrm{NH}_{4}^{+}\right]$with $2 *\left[\mathrm{SO}_{4}^{2-}\right]$ and $\left[\mathrm{NH}_{4}^{+}\right]$with $\left[\mathrm{NO}_{3}^{-}\right]$indicate the $\mathrm{NH}_{4}^{+}$in aerosol exists as $\left(\mathrm{NH}_{4}\right)_{2} \mathrm{SO}_{4}$ and $\mathrm{NH}_{3} \mathrm{NO}_{3}$.

\section{Conclusions}

The concentrations of $\mathrm{NH}_{3}$ at Beijing urban site ranged from 0.7 to $85.1 \mathrm{ppb}$, with the annual average concentrations of $18.5 \pm 13.8 \mathrm{ppb}$ and $23.5 \pm 18.0 \mathrm{ppb}$ in 2008 and 2009 , respectively. The $\mathrm{NH}_{3}$ concentrations at the rural site in Beijing were lower than those at the urban site, and varied from $0.8 \mathrm{ppb}$ to $42.9 \mathrm{ppb}$, with the annual average of $4.5 \pm 4.6$, $6.6 \pm 7.0$ and $7.1 \pm 3.5$ ppb in 2007, 2008 and 2009, respectively. $\mathrm{NH}_{3}$ concentrations were the highest in summer at both sites, and the summer to winter concentration ratios were 3.2 and 4.9 at urban and rural site, respectively. The highly amplified seasonality at the rural site may be primarily from the increased emission rates of local agricultural $\mathrm{NH}_{3}$ sources in summer.
The $\mathrm{NH}_{3}$ wind roses show that the higher values were in northeast to southwest sectors and lower values in northwest to north sectors of the Beijing urban site. The back trajectory analysis indicates that the air masses from the North China Plain region contain the highest concentration of $\mathrm{NH}_{3}$ and the air masses traveling over the coal mining and power generation regions west of Beijing contain the second highest concentrations of ammonia. Therefore, transport of air masses from these regions is responsible for the high concentrations of $\mathrm{NH}_{3}$ at Beijing urban areas.

The measurements showed significant positive correlations between hourly concentrations of $\mathrm{NH}_{3}$ with $\mathrm{NO}_{\mathrm{x}}$ and $\mathrm{CO}$ in winter in urban areas of Beijing. Since $\mathrm{NO}_{\mathrm{x}}$ and $\mathrm{CO}$ are primarily traffic related pollutants, this result points to traffic as a significant source of $\mathrm{NH}_{3}$. The contribution from vehicles is further supported by the observation of a bimodal diurnal cycle of $\mathrm{NH}_{3}$ in winter, with peaks occurring roughly at times of high traffic density.

The daily $\mathrm{NH}_{4}^{+}$concentrations ranged from 0.10 to $36.53 \mu \mathrm{g} \mathrm{m}^{-3}$, with an average concentration of $7.03 \mu \mathrm{g} \mathrm{m}^{-3}$ from June 2008 to December 2009 at the rural site. The average concentrations of $\mathrm{NH}_{4}^{+}$were $7.4 \pm 4.7,9.0 \pm 9.3$, $5.8 \pm 7.5$ and $4.7 \pm 5.1 \mu \mathrm{g} \mathrm{m}^{-3}$ in spring, summer, autumn and winter, respectively. Monthly $\mathrm{NH}_{3}$ were significantly correlated with $\mathrm{NH}_{4}^{+}$concentrations. Average monthly $\mathrm{NH}_{3} / \mathrm{NH}_{4}^{+}$ratios varied from 0.13 to 2.28 , with an average of 0.73 . The average concentrations of $\mathrm{SO}_{4}^{2-}, \mathrm{NO}_{3}^{-}$and $\mathrm{Cl}^{-}$ were $15.00,11.57$ and $1.33 \mathrm{~g} \mathrm{~m} \mathrm{~m}^{-3}$, respectively, and the total concentration of inorganic ions $\left(\mathrm{NH}_{4}^{+}+\mathrm{NO}_{3}^{-}+\mathrm{SO}_{4}^{2-}+\mathrm{Cl}^{-}\right)$ was $34.93 \mu \mathrm{g} \mathrm{m}^{-3}$. In summer, most of $\mathrm{NH}_{4}^{+}$in $\mathrm{PM}_{2.5}$ is present as $\left(\mathrm{NH}_{4}\right)_{2} \mathrm{SO}_{4}$.

Acknowledgements. This work was supported by National Natural Science Foundation of China (40975081), National Basic Research Program of China (2005CB422202), Desert Meteorological Foundation of CMA (Sqj2010012), and National Natural Science Foundation of China (40705042). The authors would like to thank Xiaobin $\mathrm{Xu}$ for his helpful support and suggestions and the plotting helps of Liang Ran in Peking University. The authors thank the staff of Shangdianzi Regional Background Station for carrying out the routine observations.

Edited by: J. G. Murphy 


\section{References}

Alebic-Juretic, A.: Airborne ammonia and ammonium within the Northern Adriatic area, Croatia, Environ. Pollut., 154, 439-447, 2008.

Aneja, V. P., Chauhan, J. P., and Walker, J. T.: Characterization of Atmospheric Ammonia Emissions from Swine Waste Storage and Treatment Lagoons, J. Geophys. Res., 105, 11535-11545, 2000.

Asman, W. A., Sutton, M. A., and Schjørring, J. K.: Ammonia: Emission, atmospheric transport and deposition, New Phytol., 139, 27-48, 1998.

Bai, Z., Dong, Y., Wang, Z., and Zhu, T.: Emission of ammonia from indoor concrete wall and assessment of human exposure, Environ. Int., 32, 303-311, 2006.

Bari, A., Ferraro, V., Wilson, L. R., Luttinger, D., and Husain, L.: Measurements of gaseous $\mathrm{HONO}, \mathrm{HNO}_{3}, \mathrm{SO}_{2}, \mathrm{HCl}, \mathrm{NH}_{3}$, particulate sulfate and $\mathrm{PM}_{2.5}$ in New York, NY, Atmos. Environ., 37, 2825-2835, 2003.

Biswas, K. F., Ghauri, B. M., and Husain, L.: Gaseous and Aerosol Pollutants During Fog and Clear Episodes in South Asian Urban, Atmos. Environ., 42, 7775-7785, 2008.

Bouwman, A. F., Lee, D. S., Asman, W. A. H., Dentener, F. J., Hoek, V. D. K. W., and Olivier, J. G. J.: A global high-resolution emission inventory for ammonia, Glob. Biogeochem. Cy., 11, 561-587, 1997.

Brunekreef, B. and Holgate, S. T.: Air pollution and health, Lancet, 360, 1233-1242, 2002.

Cao, J. J., Zhang, T., Chow, J. C., Watson, J. G., Wu, F., and Li, H.: Characterization of Atmospheric Ammonia over Xi' an, China, Aerosol and Air Quality Research, 9, 277-289, 2009.

Carmichael, G. R., Ferm, M., Thongboonchoo, N., Woo, J., Chan, L. Y., Murano, K., Viet, P. H., and Mossberg, C., Bala, R., Boonjawat, J., Upatum, P., Mohan, M., Adhikary, S. P., Shrestha, A. B., Pienaar, J. J., Brunke, E. B., Chen, T., Jie, T., Guoan, D., Peng, L. C., Dhiharto, S., Harjanto, H., Jose, A. M., Kimani, W., Kirouane, A., Lacaux, J. P., Richard, S., Barturen, O., Cerda, J. C., Athayde, A., Tavares, T., Cotrina, J. S., and Bilici, E.: Measurements of sulfur dioxide, ozone and ammonia concentrations in Asia, Africa, and South America using passive samplers, Atmos. Environ., 37, 1293-1308, 2003.

Clarisse, L., Clerbaux, C., Dentener, F., Hurtmans, D., and Coheur, P. F.: Global ammonia distribution derived from infrared satellite observations, Nature Geosci., 2, 478-483, doi:10.1038/NGEO551, 2009.

Chou, M. S. and Wang, C. H.: Treatment of Ammonia in Air Stream by Biotrickling Filter, Aerosol Air Qual. Res., 7, 17-32, 2007.

Dentener, F. J. and Crutzen, P. J.: A three-dimensional model of the global ammonia cycle, J. Atmos. Chem., 19, 331-369, 1994.

Ellis, R. A., Murphy, J. G., Pattey, E., van Haarlem, R., O’Brien, J. M., and Herndon, S. C.: Characterizing a Quantum Cascade Tunable Infrared Laser Differential Absorption Spectrometer (QCTILDAS) for measurements of atmospheric ammonia, Atmos. Meas. Tech., 3, 397-406, doi:10.5194/amt-3-397-2010, 2010.

Ellis, R. A., Murphy, J. G., Markovic, M. Z., VandenBoer, T. C., Makar, P. A., Brook, J., and Mihele, C.: The influence of gasparticle partitioning and surface-atmosphere exchange on ammonia during BAQS-Met, Atmos. Chem. Phys., 11, 133-145, doi:10.5194/acp-11-133-2011, 2011.

Galloway, J. N., Zhao, D. W., Xiong, J., and Likens, G. E.: Acid
Rain: China, US and a Remote Area, Science, 230, 1559-1562, 1987.

Galloway, J. N., Aber, J. D., Erisman, J. W., Seitzinger, S. P., Howarth, R. W., Cowling, E. B., and Cosby, B. J.: The nitrogen cascade, BioScience, 53, 341-353, 2003.

Galloway, J. N., Townsend, A. R., Erisman, J. W., Bekunda, M., Cai, Z., Freney, J. R, Martinelli, L. A., Seitzinger, S. P., and Sutton, M. A.: Transformation of the nitrogen cycle: Recent trends, questions, and potential solutions, Science, 320, 889-892, 2008.

Hao, J., Wang, L., Li, L., Hu, J. N., and Yu, X. C.: Air pollutants contribution and control strategies of energy-use related sources in Beijing, Sci. China Ser. D, 48, (Suppl. II), 138-146, 2005.

Heeb, N. V., Saxer, C. J., Forss, A.-M., and Brühlmann, S.: Trends of $\mathrm{NO}-, \mathrm{NO}_{2-}$, and $\mathrm{NH}_{3}$-emissions from gasoline-fueled Euro3- to Euro-4-passenger cars, Atmos. Environ., 42, 2543-2554, 2008.

Horvath, H.: Effects on visibility, weather and climate, in: Atmospheric acidity: sources, consequences and abatement, edited by: Radojevic, M. and Harrison, R. M., chapter 13, London: Elsevier Applied Science, 1992.

Huai, T., Durbin, T. D., Younglove, T., Scora, G., and Norbeck, J. M.: Vehicle specific power approach to estimating on-road $\mathrm{NH}_{3}$ emissions from light duty vehicles, Environ. Sci. Technol., 39, 9595-9600, 2005.

Ianniello, A., Spataro, F., Esposito, G., Allegrini, I., Rantica, E., Ancora, M. P., Hu, M., and Zhu, T.: Occurrence of gas phase ammonia in the area of Beijing (China), Atmos. Chem. Phys., 10, 9487-9503, doi:10.5194/acp-10-9487-2010, 2010.

Ju, X., Liu, X., Zhang, F., and Roelche, M.: Nitrogen fertilization, soil nitrate accumulation, and policy recommendations in several agricultural regions of China, Ambio, 33, 300-305, 2004.

Kean, A. J., Harley, R. A., Littlejohn, D., and Kendall, G. R.: On road measurement of ammonia and other motor vehicle exhaust emissions, Environ. Sci. Technol., 34, 3535-3539, 2000.

Khemani, L. T., Momin, G. A., Naik, M. S., Rao, P. S. P., Safai, P. D., and Murty, A. S. R.: Influence of Alkaline Particulates on $\mathrm{pH}$ of Cloud and Rain Water in India, Atmos. Environ., 21, 1137-1145, 1987.

Klimont, Z.: Current and Future emissions of Ammonia in China, 10th International Emission Inventory Conference: One Atmosphere, One Inventory, Many Challenges, US EPA, 1-3 May, Denver, USA, available at: http://www.epa.gov/ttn/chief/ conference/ei10/ammonia/klimont.pdf, 2001.

Kobara, H., Takeuchi, K., and Ibusuki, T.: Effect of Relative Humidity on Aerosol Generation through Experiments at Low Concentrations of Gaseous Nitric Acid and Ammonia, Aerosol Air Qual. Res., 7, 193-204, 2007.

Kulshrestha, U. C., Sarkar, A. K., Srivastava, S. S., and Parashar, D. C.: Investigation into Atmospheric Deposition through Precipitation Studies at New Delhi (India), Atmos. Environ., 30, 41494154, 1996.

Lenhard, V. and Gravenhorst, G.: Evaluation of Ammonia of Fluxes into the Free Atmosphere over Western Germany, Tellus, 328, 48-55, 1980.

Likens, G. E., Keene, W. C., Miller, J. M., and Galloway, J. N.: Chemistry of Precipitation from a Remote, Terrestrial Site in Australia, J. Geophys. Res., 92, 13299-13314, 1987.

Lin, W., Xu, X., Zhang, X., and Tang, J.: Contributions of pollutants from North China Plain to surface ozone at the 
Shangdianzi GAW Station, Atmos. Chem. Phys., 8, 5889-5898, doi:10.5194/acp-8-5889-2008, 2008.

Lin, W., Xu, X., Ge, B., and Liu, X.: Gaseous pollutants in Beijing urban area during the heating period 2007-2008: variability, sources, meteorological and chemical impacts, Atmos. Chem. Phys. Discuss., 11, 6919-6956, doi:10.5194/acpd-116919-2011, 2011.

Matthews, E.: Nitrogenous fertilizers: Global distribution of consumption and associated emissions of nitrous oxide and ammonia, Glob. Biogeochem., 8, 411-439, 1994.

Meng, Z. Y., Jiang, X. M., Yan, P., Lin, W. L., Zhang, H. D., and Wang, Y.: Characteristics and sources of $\mathrm{PM}_{2.5}$ and carbonaceous species during winter in Taiyuan, China, Atmos. Environ., 41, 6901-6908, 2007.

Meng, Z. Y., Xu, X. B., Yan, P., Ding, G. A., Tang, J., Lin, W. L., Xu, X. D., and Wang, S. F.: Characteristics of trace gaseous pollutants at a regional background station in Northern China, Atmos. Chem. Phys., 9, 927-936, doi:10.5194/acp-9-927-2009, 2009.

Meng, Z. Y., Xu, X. B., Wang, T., Zhang, X. Y., Yu, X. L., Wang, S. F., Lin, W. L., Chen, Y. Z., Jiang, Y. A., and An, X. Q.: Ambient sulfur dioxide, nitrogen dioxide, and ammonia at ten background and rural sites in China during 2007-2008, Atmos. Environ., 44, 2625-2631, 2010.

Nemitz, E., Milford, C., and Sutton, M. A.: A TwoLayer Canopy Compensation Point Model for Describing Bidirectional Biosphere-Atmosphere Exchange of Ammonia, Q. J. Roy. Meteorol. Soc., 127, 815-833, 2001.

Perrino, C., Catrambone, M., Di Menno Di Bucchianico, A., and Allegrini, I.: Gaseous ammonia in the urban area of Rome, Italy, and its relationship with traffic emissions, Atmos. Environ., 36, 5385-5394, 2002.

Possanzini, M., Buttini, P., and Dipalo, V.: Characterization of a Rural Area in Terms of Dry and Wet Deposition, Sci. Total. Environ., 74, 111-120, 1988.

Robarge, W. P., Walker, J. T., McCulloch, R. B., and Murray, G.: Atmospheric concentrations of ammonia and ammonium at an agricultural site in the southeast United States, Atmos. Environ., 36, 1661-1674, 2002.

Saylor, R. D., Edgerton, E. S., Hartsell, B. E., Baumann, K., and Hansen, D. A.: Continuous gaseous and total ammonia measurements from the southeastern aerosol research and characterization (SEARCH) study, Atmos. Environ., 44, 4994-5004, 2010.

Streets, D. G., Bond, T. C., Carmichael, G. R., Fernandes, S. D., Fu, Q., He, D., Klimont, Z., Nelson, S. M., Tsai, N. Y., Wang, M. Q., Woo, J. H., and Yarber, K. F.: An inventory of gaseous and primary aerosol emissions in Asia in the year 2000, J. Geophys. Res.-Atmos., 108(D21), 8809, doi:10.1029/2002JD003093, 2003.
Suh, H. H,. Allen, G. A., Koutrakis, P., and Burton, R. M.: Spatial variation in acidic sulphate and ammonia concentrations within metropolitan Philadelphia, J. Air Waste Manage. Assoc., 45, 442-452, 1995.

Sutton, M. A., Asman, W. A. H., and Schjørring, J. K.: Dry deposition of reduced nitrogen, Tellus, 46B, 255-273, 1994.

Sutton, M. A., Dragostis, U., Tang, Y. S., and Fowler, D.: Ammonia emissions from non-agricultural sources in the UK, Atmos. Environ., 34, 855-869, 2000.

Tanner, P.: Vehicle-related ammonia emissions in Hong Kong, Environ. Chem. Lett., 7, 37-40, 2009.

Tuncel, S. G. and Ungor, S.: Rain Water Chemistry in Ankara, Turkey, Atmos. Environ., 30, 2721-2727, 1996.

Walker, J. T., Whitall, D., Robarge, W. P., and Paerl, H.: Ambient ammonia and ammonium aerosol across a region of variable ammonia emission density, Atmos. Environ., 38, 1235-1246, 2004.

Wang, B., Shao, M., Lu, S. H., Yuan, B., Zhao, Y., Wang, M., Zhang, S. Q., and Wu, D.: Variation of ambient non-methane hydrocarbons in Beijing city in summer 2008, Atmos. Chem. Phys., 10, 5911-5923, doi:10.5194/acp-10-5911-2010, 2010.

Whitehead, J. D., Longley, I. D., and Gallagher, M. W.: Seasonal and diurnal variation in atmospheric ammonia in an urban environment measured using a quantum cascade laser absorption spectrometer, Water Air Soil Poll., 183, 317-329, 2007.

Wu, Z. J., Hu, M., Shao, K. S., and Slanina, J.: Acidic gases, $\mathrm{NH}_{3}$ and secondary inorganic ions in $\mathrm{PM}_{10}$ during summertime in Beijing, China and their relation to air mass history, Chemoshere, 76, 1028-1035, 2009.

Yao, X. H., Lau, A. P. S., Fang, M., Chan, C. K., and Hu, M.: Size distributions and formation of ionic species in atmospheric particulate pollutants in Beijing, China: 1-inorganic ions, Atmos. Environ., 37, 2991-3000, 2003.

Yao, X. H., Ling, T. Y., Fang, M., and Chan, C. K.: Comparison of Thermodynamic Predictions for in Situ $\mathrm{pH}$ in $\mathrm{PM}_{2.5}$, Atmos. Environ., 40, 2835-2844, 2006.

Zhang, Y., Dore, A. J., Ma, L., Liu, X. J., Ma, W. Q., Cape, J. N., and Zhang, F. S.: Agricultural ammonia emissions inventory and spatial distribution in the North China Plain, Environ. Pollut., 158, 490-501, 2010. 